\title{
The Causation between Inflation and Currency Devaluation: The Case of Iran
}

\author{
Abbas P. Grammy* \\ Department of Economics \\ California State University, Bakersfield \\ 9001 Stockdale Highway \\ Bakersfield, CA 93311, United States \\ Najmeh Kamyabi \\ Department of Economics \\ California State University, Bakersfield \\ 9001 Stockdale Highway \\ Bakersfield, CA 93311, United States
}

\begin{abstract}
In this paper, we demonstrate that the Iranian economy has experienced rapid and variable inflation and sharp and frequent currency devaluation. In addition, we detect correlation patterns between inflation and exchange rate by way of Granger-causality testing. We also identify a significant shift in both inflation and exchange rate time-series in 1980, right after theocracy replaced monarchy. Taking this structural shift into consideration, we detect no causal correlation patterns in the pre-revolution era. However, with inflation accelerating and currency devaluating, we discover that inflation Granger-causes exchanged rate and exchange rate Granger-causes inflation in the postrevolution period. We discuss that the key to breaking these correlation patterns is to increase the supply of foreign exchange from oil and non-oil exports in order to restore and stabilize the foreign exchange rate. To achieve this end, Iran must fully renovate its politico-economic system in order to lower political risk and brighten business climate.
\end{abstract}

Keywords: Inflation, Exchange Rate, Currency Devaluation, Granger-Causality Test, Structural Shift

JEL Classifications: Development Economics (O1), Economy-wide Country Study (O5), General Macroeconomics (E0)

\section{Introduction}

Inflation and inflation variability have been major concerns for the Iranian economy. During the past seventy years (1948-2017), the rate of CPI inflation had a mean of 12.0 percent and standard deviation of 8.8 percent. Inflation has surged and inflation variability has accelerated since the establishment of theocracy in late 1979. Prior to this political shift, the inflation rate recorded a mean of 5.5 percent and standard deviation of 5.7 percent, peaking to 26.2 percent in 1977. However, inflation accelerated and inflation variability speeded in the post-revolution era. The rate of inflation had a mean of 17.4 percent and a standard deviation of 7.2 percent, with asharphiketo 40 percent in 1995 and occasional spikes varying between 20 to 30 percent. $^{1}$

\begin{tabular}{|c|c|c|}
\hline Time Period & $\begin{array}{l}\text { Inflation Rate } \\
(\%)\end{array}$ & Exchange Rate (IRR/USD) \\
\hline $1948-2017$ & $\begin{array}{l}12.0 \\
8.8 \\
0.3-40.0\end{array}$ & $\begin{array}{l}4,819.44 \\
10,060.72 \\
32.25-42,962.80\end{array}$ \\
\hline $1948-1979$ & $\begin{array}{l}5.5 \\
5.7 \\
0.3-26.2 \\
\end{array}$ & $\begin{array}{l}61.41 \\
19.08 \\
32.25-75.75\end{array}$ \\
\hline $1980-2017$ & $\begin{array}{l}17.4 \\
7.2 \\
5.4,40.0 \\
\end{array}$ & $\begin{array}{l}8,826.21 \\
12,356.78 \\
70.65-42,962.80\end{array}$ \\
\hline \multicolumn{3}{|c|}{$\begin{array}{l}\text { Numbers are the mean, standard deviation, and rang } \\
\text { respectively. }\end{array}$} \\
\hline
\end{tabular}


Meanwhile, the Iranian currency has depreciated sharply. The rate of exchange of the Iranian rial (IRR) to the United States dollar (USD) averaged 4,819 with a variability of 10,060 in the past seventy years. In the pre-revolution era, the IRR/USD rate recorded a mean of 61 with a standard deviation of 19. Although the rate depreciated abruptly in 1957, it remained relatively stable afterward, varying within the $(68,76)$ range. In the post-revolution era, however, the IRR/USD mean ballooned to 8,826 with a variability of 12,357 . The official IRR/USD exchange rate depreciated from 71 in 1980 to 42,963 in 2017 . Noticeably, the exchange rate breaking the 10,000-mark in 2010, quadrupled inthe following seven years. ${ }^{2}$

In late 2018, Iran's annual inflation rate as measured by Hanke (2018) was estimated at 236 percent (vs. the official rate of 15.9 percent). ${ }^{3}$ In the meantime, the IRR/USD exchange rate continued to plunge to an all-time record of 170,000 (vs. the official rate of about 42,963). ${ }^{4}$ To measure inflation, Hanke forecasts the effect of exchange rate variations on price increases by way of regression analysis using historical data. ${ }^{5}$ In our database, we calculate a positive and significant correlation between CPI inflation rate and IRR/USD conversion rate $(r=0.72, t=8.05)$. However, the correlation coefficient being insignificant in the pre-revolution era $(\mathrm{r}=0.17, \mathrm{t}=1.10)$ increases and turns significant in the years of post-revolution $(\mathrm{r}=0.53, \mathrm{t}=4.57)$.

A reason for Iran's inflation-exchange rate correlation is its large volume of imported capital and consumer goods (relative to a small volume of non-oil exports), whose prices are inflated by a depreciating exchange rate. In turn, inflated import-prices transition into prices producers and consumers pay for domestic goods and services. As inflation accelerates, domestic goods and services become less competitive in regional markets, resulting in reduced demand for exports and falling demand for the IRR. Now, domestic producers and consumers, who find foreign goods and services relatively less expensive, supply more currency to pay for imports. As a result of a falling demand and a rising supply, the currency loses more value.

Another reason for Iran's inflation-exchange rate correlation is perceived undesirability for holding the IRR. Investors' perception is affected adversely by Iran's excessive political risk(index of 6.8 out of 7.0) ${ }^{6}$ and gloomy business climate (evaluation grade of D). ${ }^{7} \mathrm{~A}$ wide range of factors contribute to Iran's politico-economic imbalance, including rapid inflation, high unemployment, social tension, involvement in international dispute and regional conflict, widespread corruption, difficult business relations, stringent government regulations, unreliable banking transactions, and unpredictable legal system. In addition to profitability, investors' main consideration is safety of holding cash assets in a national currency. When a nation is perceived to be economically unstable and politically inapt, investors shy away from making long-term commitment and become reluctant to hold the currency for significant periods of time and in large amounts.

With this background, the correlation pattern between Iran's inflation rate and foreign exchange rate is a paramount empirical question. As such, this paper is an empirical assessment of the causal relationship between inflation and exchange rate in an economy that has experienced a major political change. In doing so, we will conduct Grangercausality tests to explore the existence and direction of inflation-exchange rate relationship during the past seventy years as well as pre- and post-revolution periods. To achieve this task, we organize the paper in the following manner. Section 2 offers a review of relevant literature. Sections 3 outlines the research methodology and section 4 presents the test results. The final section is conclusion.

\section{Review of Relevant Literature}

A growing number of researchers have shown interest in the examination of causal relationship between monetary indicators in developing countries. The study by Deme and Fayissa (1995) provided evidence on Granger-causality between inflation and money supply growth and between inflation and exchange rate in Egypt, Morocco, and Tunisia. Hossain (2005) suggested bidirectional causality between money supply growth and inflation and between currency devaluation and inflation in Indonesia. The study by Zhu (2012) showed a causal relationship from changes in exchange rate (dollar and yen to yuan) to inflation in China. However, no evidence was found for causality from inflation to changes in exchange rate.

Likewise, Amoah, Nyarko, and Asare (2015) detected unidirectional causality between GDP growth rate and exchange rate and bidirectional causality between inflation rate and exchange rate and between inflation rate and GDP growth rate in Ghana. Lado (2015) revealed the existence of unidirectional causality from exchange rate to inflation without feedback, concluding that currency devaluation has been detrimental to the economy of South Sudan. Ali Khan, Sattar, Rehman (2015) detected no causal relationship between exchange rate and inflation, but a causal relationship between exchange rate and trade, and between exchange rate and foreign direct investment in Pakistan. 
Mohammed and Dahalan (2016), conducting an asymmetric causality test, revealed that policies to prevent inflationshocks could stabilize real exchange rate in Malaysia, the Philippines, and South Africa, but not vice versa. Likewise, David and Oluseyi (2017) estimated a significant relationship between currency devaluation and real GDP growth, and between currency devaluation and external debt, but insignificant relationship between currency devaluation and private domestic investment in Nigeria. Gocmen (2016) found a feedback relationship between money supply growth and inflation in Turkey. However, causality from inflation to money supply growth was stronger than causality from money supply growth to inflation. Monfared and Akin (2017) found that money supply growth and currency devaluation accelerated inflation in Iran with the contribution of the money supply growth on inflation being stronger than the effect of exchange rate on inflation.

Malaysia has been a popular case study for the Granger-causality testing. Rehman and Aftab (2015) estimated a longrun relationship between interest rate and exchange rate, and between inflation and exchange rate. Yien, Abdullah, and Azam (2017) provided evidence that inflation Granger-caused domestic debt, exchange rate Granger-caused inflation, and domestic debt Granger-caused exchange rate. Khin, Yee, Seng, Wan, Xian (2017) stated that the outcome of Granger-causality test confirmed a bidirectional causal relationship between exchange rate and money supply growth rate. They detected unidirectional causality between inflation and exchange rate, and between interest rate exchange rate.

Our contribution to the relevant literature is twofold. First, we test the inflation-exchange rate Granger-causality hypothesis in Iran's hyper-inflationary environment. Next, we apply the causality test to this economy that has experienced a political shift. Within this context, we discover the existence and direction of the inflation-exchange rate causality in years of per- and post-revolution. Based on test results, we will examine the idea of curbing inflation by way of restoration and stability of the IRR/USD conversation rate.

\section{Research Methodology}

We consider a tri-variate VAR model comprised of the general price level $(\mathrm{P})$, monetary base (M), and foreign exchange rate (E). As macroeconomic series are at most I(2), we follow Johnson (1995) and use VAR(p) model in vector error correction representation,

$p-1$

$\Delta \mathrm{x}_{\mathrm{t}}=\Pi \mathrm{x}_{\mathrm{t}-\mathrm{p}}+\sum \Gamma \Delta \mathrm{x}_{\mathrm{t}-\mathrm{i}}+\mu_{0}+\mu_{1 \mathrm{t}}+\varepsilon_{\mathrm{t}}$

$\mathrm{i}=1$

here, $X_{t}=\left(P_{t}, M_{t}, E_{t}\right), \Pi$ and $\Gamma$ are matrices of parameters, $\mu_{0}$ and $\mu_{1}$ are vectors of constant and trend coefficients, respectively, and $\Delta$ is the difference operator. Granger causality requires variables that are time invariant (stationary) and that do not diverge from each other in the long-run (co-integration). As such, $\Pi$ describes the long-run matrix of parameters that determine the co-integrating relationship among the elements of $X_{t}$. For example, if the null hypothesis of no co-integration among the elements of $X_{t}$ is rejected, causality must run in at least one direction. Granger's representation theorem proves that a co-integrated system of variables can be represented in three possible forms: vector autoregression, vector error correction, or moving average forms (Barnajee et al. 1993). Drawing upon a framework employed by Canova (1995) and Sinha and Sinha (1998), the underlying causality relationship can be tested using the bloc decomposition vector error correction representation, which is explicitly written as:

$$
\begin{aligned}
& \triangle \ln \left(P_{t}\right)=\alpha_{0}+\alpha_{1 t}+\eta_{1} \nu_{t-1}+\sum_{i=1}^{p} \theta_{1, i} \Delta \ln \left(P_{t-i}\right)+\sum_{i=1}^{p} \theta_{2, i} \triangle \ln \left(M_{t-i}\right)+\sum_{i=1}^{p} \theta_{3, i} \Delta \ln \left(E_{t-i}\right)+\varepsilon_{1 t} \\
& \triangle \ln \left(E_{t}\right)=\beta_{0}+\beta_{1 t}+\eta_{2} \nu_{t-1}+\sum_{i=1}^{p} \lambda_{1, i} \Delta \ln \left(P_{t-i}\right)+\sum_{i=1}^{p} \lambda_{2, i} \Delta \ln \left(M_{t-i}\right)+\sum_{i=1}^{p} \lambda_{3, i} \Delta \ln \left(E_{t-i}\right)+\varepsilon_{2 t}
\end{aligned}
$$

where $\alpha, \beta, \theta$, and $\lambda$ are coefficients, $p$ is the maximum lag length, and $\varepsilon_{1 \mathrm{t}}$ and $\varepsilon_{2 \mathrm{t}}$ are error terms not serially correlated. Likewise, $v_{\mathrm{t}-1}$ is the lagged value of the co-integrating vector, $\eta_{1}$, and $\eta_{2}$ are adjustment coefficients. We conduct blocksof hypothesis testing for Granger causality between all three variables. For example, inflation does not Grangercause exchange rate if we fail to reject $\mathrm{H}_{0}: \theta_{3, \mathrm{i}}=0$. Likewise, exchange-rate does not Granger-cause inflation if we fail to reject $\mathrm{H}_{0}: \lambda_{1, \mathrm{i}}=0$. 


\section{Test Results}

To begin, we examine the stationary requirement of the three variables expressed in logarithmic form by way of the augmented Dickey-Fuller (ADF) test and Phillips-Perron (PP) test. The test results presented in Table 2 indicate that all variables are non-stationary in levels. However, they are stationary in first differences as the null hypothesis of nonstationary is rejected at the one-percent significance level. In addition, Table 3 presents results for Johansen cointegration test. In both the trace test and maximum eigenvalue test, the computed test-stat being greater than its critical value indicates rejection of the null hypothesis of no co-integration. Thus, test results indicate existence of a unique cointegrating factor, ensuring a stable long-run relationship between the variables.

\begin{tabular}{|l|l|l|l|l|}
\hline \multicolumn{4}{|l|}{ Table 2. Stationary Test Results } \\
\hline & ADF Test & \multicolumn{2}{l|}{ PP Test } \\
\hline Variables & Levels & First Differences & Levels & First Differences \\
\hline$\Delta \ln (\mathrm{P})$ & 4.892 & $-3.616^{*}$ & -2.131 & $-4.395^{*}$ \\
\hline$\Delta \ln (\mathrm{E})$ & 2.162 & $-5.558^{*}$ & -1.262 & $-5.947^{*}$ \\
\hline$\Delta \ln (\mathrm{M})$ & 5.995 & $-3.234^{*}$ & -1.519 & $-4.554^{*}$ \\
\hline $\begin{array}{l}\text { The * mark indicates significance at the 1\% level. The order of lag is one as } \\
\text { determined by the Akaike information criterion. }\end{array}$ \\
\hline
\end{tabular}

\begin{tabular}{|l|l|l|}
\hline \multicolumn{3}{|l|}{ Table 3. Multivariate Co-integration Test Results } \\
\hline Trace Test & Test-Stat & Critical Value \\
\hline $\mathrm{r}=0$ & $29.68^{* *}$ & 26.74 \\
\hline $\mathrm{r}=1$ & 7.90 & 15.41 \\
\hline $\mathrm{r}=2$ & 0.54 & 3.76 \\
\hline \multicolumn{3}{|l|}{} \\
\hline Maximum Eigenvalue Test & $21.85^{* *}$ & 20.97 \\
\hline $\mathrm{r}=0$ & 7.36 & 14.07 \\
\hline $\mathrm{r}=1$ & 0.53 & 3.76 \\
\hline $\mathrm{r}=2$ & $\begin{array}{l}\text { The co-integration tests are based on } \ln (\mathrm{P}), \ln (\mathrm{E}) \text {, and ln(M). The order of lag } \\
\text { is two as selected by the Akaike information criterion. The log-likelihood } \\
\text { criteria values are used and the ** mark indicates significant at the 5\% level. }\end{array}$ \\
\hline
\end{tabular}

Having stationary and co-integrated time-series, we apply the Granger-causality test. Results based on the vector error correction model are presented in Table 4. Since model variables are I(1), the Granger-causality test yields results that are also valid when these variables are expressed in log-first-difference. The test results are consistently robust for both bivariate and multivariate models as computed values of the F-stat are greater than their critical values. In the inflation equation, the decision rule is to reject the null hypothesis of inflation does not Granger-causing exchange rate. Likewise, test results lead us to reject the null hypothesis that exchange rate does not Granger-cause inflation.

\begin{tabular}{|l|l|l|l|}
\hline \multicolumn{4}{|l|}{ Table 4. Causality Test Results } \\
\hline Time Period: $1948-2017$ & $\begin{array}{l}\text { Decision } \\
\text { Rule }\end{array}$ & $\begin{array}{l}\text { Bivariate } \\
\text { Model }\end{array}$ & $\begin{array}{l}\text { Multivariate } \\
\text { Model }\end{array}$ \\
\hline & & F-stat & F-stat \\
\hline $\mathrm{H}_{0}: \Delta \ln (\mathrm{P})$ does not Granger-cause $\Delta \ln (\mathrm{E})$ & Reject $\mathrm{H}_{0}$ & $12.31^{*}$ & $7.22^{*}$ \\
\hline $\mathrm{H}_{0}: \Delta \ln (\mathrm{E})$ does not Granger-cause $\Delta \ln (\mathrm{P})$ & Reject $\mathrm{H}_{0}$ & $5.28^{*}$ & $4.99^{*}$ \\
\hline The $*$ mark indicates significance at the $1 \%$ level. \\
\hline
\end{tabular}

Prior to testing inflation-exchange rate causality in the pre- and post-revolution era, we conducted a series of Chow test of structural shift. In these tests, the unrestricted model includes data points from 1948-2017. The restricted models contain data points in the pre- revolution era (1948-1979) and post-revolution period (1980-2017). As shown in Table 5 and depicted in Figures 1 and 2, we detect significant structural breaks in inflation rate and exchange rate time-series. With computed F-stat values greater than their critical values, we reject the null hypothesis of no structural shift in 1980. 


\begin{tabular}{|l|l|l|}
\hline \multicolumn{3}{|l|}{ Table 5. Structural Shift Test Results } \\
\hline Structural Shift: 1980 & $\begin{array}{l}\text { Decision } \\
\text { Rule }\end{array}$ & F-stat \\
\hline $\mathrm{H}_{0}:$ Not Structural Shift in Inflation Time-Series & Reject $\mathrm{H}_{0}$ & $29.89^{*}$ \\
\hline $\mathrm{H}_{0}:$ No Structural Shift in Exchange Rate Time-Series & Reject $\mathrm{H}_{0}$ & $26.78^{*}$ \\
\hline The $*$ mark indicates significance at the $1 \%$ level. & \\
\hline
\end{tabular}
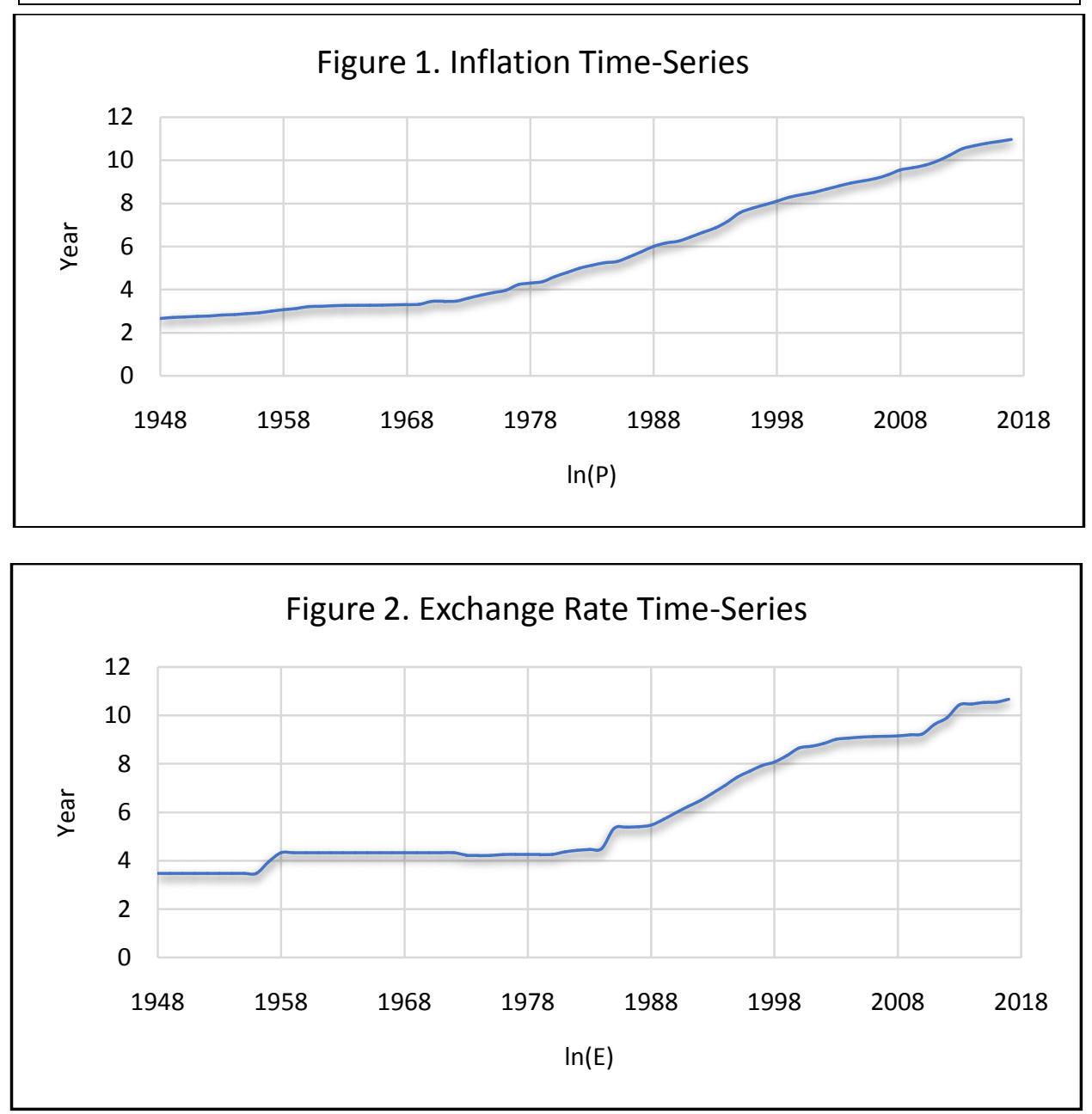

Upon detecting structural shifts in inflation and exchange rate time-series, we examine Granger-causality between inflation and exchange rate in years of pre- and post-revolution. Causality test results are presented in Table 6. In both bivariate and multivariate models, low values of the F-stat indicate failure to reject the null hypothesis of no Grangercausality in the pre-revolution era. Hence, test results indicate that inflation did not Granger-cause exchange rate, and exchange rate did not Granger-cause inflation in 1948-1979.

In the post-revolution era, however, we detect significant bidirectional Granger-causality. In both bivariate and multivariate models, high values of the F-stat indicate rejection of the null hypothesis of no Granger-causality. Hence, test results indicate that inflation Granger-causes exchange rate and exchange rate Granger-causes inflation. Considering a significant structural shift in 1980, we detected significant correlation patterns between inflation and exchange rate in 1980-2017. 


\begin{tabular}{|l|l|l|l|}
\hline \multicolumn{5}{|l|}{ Table 6. Causality Test Results } & $\begin{array}{l}\text { Bivariate } \\
\text { Model }\end{array}$ & $\begin{array}{l}\text { Multivariate } \\
\text { Model }\end{array}$ & Decision Rule \\
\hline Time Period: $1948-1979$ & F-stat & F-stat & \\
\hline $\mathrm{H}_{0}: \Delta \ln (\mathrm{P})$ does not Granger-cause $\Delta \ln (\mathrm{E})$ & 1.73 & 1.98 & Fail to Reject $\mathrm{H}_{0}$ \\
\hline $\mathrm{H}_{0}: \Delta \ln (\mathrm{E})$ does not Granger-cause $\Delta \ln (\mathrm{P})$ & 0.07 & 0.81 & Fail to Reject $\mathrm{H}_{0}$ \\
\hline Time Period: $1980-2017$ & & & \\
\hline $\mathrm{H}_{0}: \Delta \ln (\mathrm{P})$ does not Granger-cause $\Delta \ln (\mathrm{E})$ & $6.10^{*}$ & $3.20^{* *}$ & Reject $\mathrm{H}_{0}$ \\
\hline $\mathrm{H}_{0}: \Delta \ln (\mathrm{E})$ does not Granger-cause $\Delta \ln (\mathrm{P})$ & $5.79^{*}$ & $3.18^{* *}$ & Reject $\mathrm{H}_{0}$ \\
\hline The asterisks $*$ and $* *$ indicate significance at the $1 \%$ and $5 \%$ level, respectively. \\
\hline
\end{tabular}

\section{Conclusion}

Our empirical results indicated that the Iranian economy has experienced rapid and variable inflation and sharp and frequent currency devaluation. We tested Granger-causation between inflation and exchange rate. Our results also identified a significant shift in both inflation and exchange rate time-series in 1980, right after the country's revolution. As such, we detected no causal relationship in the pre-revolution era. With inflation accelerating and currency devaluating, we discovered that inflation Granger-caused exchanged rate and exchange rate Granger-caused inflation in the post-revolution period. The key to breaking these correlation patterns is to increase the supply of foreign exchange from oil and non-oil exports to restore and stabilize the IRR/USD conversion rate. In doing so, Iran must fully renovate its politico-economic system in order to lower political risk and brighten business climate. To achieve these objectives, Iran must curb inflation, create jobs, alleviate social tension, endinternational dispute and regional conflict, curtail corruption, restore business trust, soften government grasp, overhaul banking transactions, and modernize the legal system.

\section{Notes}

${ }^{1}$ Main sources of data the Central Bank of Iranand Federal Reserve Bank of St. Louis.

${ }^{2}$ Ibid.

${ }^{3}$ Hanke (October 2, 2018).

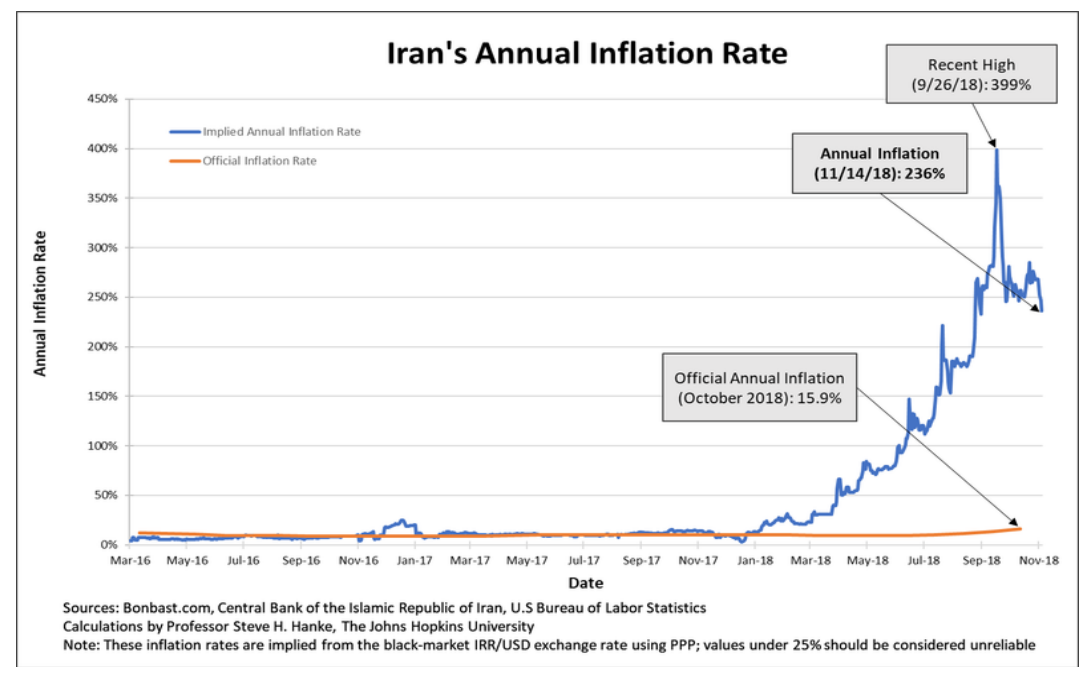

${ }_{5}^{4}$ Live Exchange Rates in Free Market of Iran (September 26, 2018).

${ }^{5}$ Iranian economists confirm that Hanke's inflation measurement is more accurate than calculation of inflation by the Central Bank. For example, Mohammed G. Yousefi acknowledges that most of capital and consumer goods are imported, thus their prices are influenced by exchange rate variations. According to Yousefi, 'Exchange rate even affects non-commercial goods such as taxi fares. 
Therefore, the exchange rate index is more accurate to assess the inflation rate.' See Islamic Republic News Agency (January 7, 2019).

${ }^{6}$ TheGlobalEconomy.com

${ }^{7}$ GlobalEdge.com

\section{References}

Ali Khan, R. E., Sattar, R., and Rehman, H. (2015). Effectiveness of Exchange Rate in Pakistan: Causality, Pakistan Journal of Commerce, 6, 1, 83-96.

Amoah, Nyarko, and Asare (2015). FDI, Exchange rate and Growth in Ghana: Evidence from Causality and Cointegrated Analysis. European Scientific Journal, 11, 31, 294-304.

Barnajee, A. Donaaldo, Galbraith, J. and Hendry, D. (1993). Coinegration, Error-Correction, and the Econometric Analysis of Non-Stationary Data, Oxford: Oxford University Press.

Canova, F. (1995). Vector Autoregressive Model. Handbook of Applied Econometrics, Vol. 1 (eds.), M. H. Pesaran and M. Wickens. Oxford: Blackwell.

David, O. O. K. and Oluseyi, A. S. (2017). Currency Devaluation and Macroeconomic Variables Responses in Nigeria: A Vector Error Correction Model Approach: 1986-2016. Journal of Finance and Economics, 5, 6, 281-289.

Deme, M. and Fayissa, B. (1995). Money, Interest Rate, Exchange Rate and Causality: The Case of Egypt, Morocco, and Tunisia. Applied Economics, 27, 12, 1219-1224.

GlobalEdge.com, https://globaledge.msu.edu/countries/iran/risk.

Gocmen, T. (2016). Causal Relationship between Money and Inflation during a High Inflationary Period: The Case of Turkey. Journal of International Business and Economics, 4, 2, 1-11.

Hanke, S. (October 2, 2018). Iran’s Annual Inflation Rate,https://twitter.com/steve_hanke?lang=en.

Hossain, M. S. (2005). Multivariate Granger Causality between Economic Growth, Electricity Consumption, Exports and Remittance for the Panel of Three SAARC Countries. Global Journal of Management and Business Research, 12, 4, 41-54.

Islamic Republic News Agency, (January 7, 2019). Economists Review Hanke's Claim on Iran Inflation Rate, http://www.irna.ir/en/News/82985156.

Johansen, S. (1995). Likelihood-based Inference in Coingegrated Vector Autoregressive Models. Oxford university Press.

Khin, A. A., Yee, C.Y., Seng, L. S., Wan, C. M., and Xian, G. O. (2017). Exchange Rate Volatility on Macroeconomic Determinants in Malaysia: Vector Error Correction Method. Journal of Global Business and Social Entrepreneurship, 3, 5, 36-45.

Lado, E. P. Zacharia (2015). Test of Relationship between Exchange Rate and Inflation in South Sudan: GrangerCausality Approach. Economics, 4, 2, 34-40.

Live Exchange Rates in Free Market of Iran, (September 26, 2018).https://www.bonbast.com/.

Mohammed, U. and Dahalan, J. (2016). Asymmetric Exchange Rate and Inflation Causality based on Toda-Yamamoto Dynamic Granger Causality Test. Actual Problems of Economics, 5, 179, 430- 440.

Monfared, S. S. and Akin, F. (2017). The Relationship between Exchange Rates and Inflation: The Case of Iran. European Journal of Sustainable Development, 6, 4, 329-340.

Rehman, I. U., \&Aftab, M. (2015). On the Linkages between Exchange Rate, Inflation and Interest Rate in Malaysia: Evidence from Autoregressive Distributed Lag Modelling. Pakistan Journal of Statistics, 31, 5, 609-622.

Sinha, D. and Sinha, T. (1998). Cart before the Horse? The Saving-Growth Nexus in Mexico. Economic Letters, 61, 43-47.

TheGlobalEconomy.com, https://www.theglobaleconomy.com/Iran/political_risk_long_term/

Yien, L. C., Abdullah, H., and Azam, M. (2017). Granger Causality Analysis between Inflation, Debt and Exchange Rate: Evidence from Malaysia, International Journal of Academic Research in Accounting, Finance and Management Sciences, 7, 1, 189-196.

Zhu, B. (2012). Exchange rate and price: A Granger Causality Test of Consumer Price Index in China. H. Tan (ed.), Technology for education and learning, 89-94, Berlin: Springer-Verlag. 